\title{
Land and justice in South Africa
}

\author{
Siobhan O'Sullivan
}

Department of Sociology, School of Sociology and Philosophy, UCC

\section{Introduction}

When Nelson Mandela took office on 10th May 1994 as South Africa's first democratic president, he pledged that out of "an extraordinary human disaster" would come "a society of which all humanity will be proud". Since then, South Africa has been praised for overcoming racial division and hatred in a peaceful manner while developing economic growth. This positive picture of post-apartheid South Africa has been compromised in recent years by rising crime, xenophobic violence, unemployment, and service-delivery protests.

My research looks at how the new democracy has redistributed land and why less than $1 \%$ of the population still own the majority of the land. To understand the slow pace of land reform, I have examined the policies of the ANC, the polarised public debates on land reform, and the constraints on economic transformation. In order to achieve justice and ultimately reconciliation, problems with redistribution must be addressed. This requires not only more financial investment but also a significant review of policy direction, principles and priorities.

\section{The History of Land Injustice in South Africa}

The "extraordinary human disaster" of apartheid in South Africa has its roots in a longer legacy, that of colonialism. Prior to colonial settlement, hunter-gatherers, pastoralists (herders) and mixed farmers populated the region for millennia. In 1652, the Dutch East India Company set up a base in what later became Cape Town. The policy of colonial rule regarding the native inhabitants was two-fold - direct rule and indirect rule. Direct rule by the British and the other settlers (Dutch, German and French who formed the Afrikaner/Boer grouping) involved destroying the local communities through slavery, land dispossession and armed conflict.

Indirect rule separated the black population into tribal reserves, called Bantustans or homelands, governed by Native Authorities. 7\% of land was allocated for these reserves under the 1913 Land Act and increased to 13\% in 1936. The amount of land black people could farm in the reserves was limited to three hectares, enough for sustaining a family 
but not to earn a living. The purpose of this was to create a mobile labour force to work in the gold and diamond mines, commercial farms and industry. Family life was destroyed in this process. White governments supported white agriculture, jobs and industry through subsidies and job guarantees, and ensured blacks would provide a cheap labour force.

Apartheid, which began in 1948 under the National Party, cemented these policies. Millions of black, coloured and Indian people were forcibly moved from cities to townships on the outskirts. They could commute to work, but cities would be 'white by night'. In rural areas, black people were moved from 'black-spots' in white designated areas to ten self-governing reserves. By the end of apartheid in 1994, over a third of the total population (16m people) lived in the overcrowded and poorly resourced Bantustans. Millions more lived in townships and squatter camps with inadequate housing, no sanitation, poor water supply and no electricity.

The first democratic elections were held in April 1994. This followed a long and international campaign, four years of negotiation and periods of intense violence and state repression. Over $19 \mathrm{~m}$ people voted, the vast majority for the first time in their lives. It was a celebrated moment in human history, with great hope that peace, justice and human dignity would become possible for all South Africa's citizens.

\section{Land Reform and Reparative Justice}

By the end of apartheid, South Africa was one of the most unequal societies in the world. In 2001, the population was almost 45m, over 10 times that of Ireland. According to that year's census non-whites accounted for over $90 \%$ of the population. Yet in 1994, 60,000 white-owned farms occupied $70 \%$ of the land, approximately $85.2 \mathrm{~m}$ hectares out of a total of $122.5 \mathrm{~m}$ hectares. The support for whites and discrimination against blacks resulted in a two-tier agricultural system: industrialised farming for whites, and small-scale subsistence farming for blacks.

Addressing this legacy and creating a reconciled nation has been one of the major aims of the four ANC-led governments since 1994. The Reconstruction and Development Programme (RDP) (a redistribution programme) and a Truth and Reconciliation Commission (TRC) were set up in the early years of democracy. Land reform is key to the RDP, and is guaranteed by the human-rights based Constitution and a series of acts developed over the past sixteen years.

Overall, these policies form part of reparative justice. Across the world, various groups e.g. victims of war, the Holocaust, slavery, and indigenous communities decimated by colonialism, have sought reparative justice. This process aims to achieve reconciliation and prevent horrific abuses from happening again. Reparative justice proposes that what was wrongfully taken in the past should be returned, victims should be shown respect, 
relationships mended and a more equal society created. It involves two forms, the acknowledgement of hurt and economic redress for that hurt, and I argue that both are required for reconciliation:

Symbolic acknowledgement of hurt can involve public apologies, remembrance ceremonies and the creation of memorials and museums. Examples in South Africa include the Apartheid Museum and the Soweto Museum in Johannesburg, the Slave Lodge in Cape Town and the celebration of Freedom Day on the 27th April. In a divided society, a new moral balance must be developed. This requires changes in cultural values such as a change of racist attitudes, and the recognition that what happened in the past was wrong. Accountability and forgiveness, respect for democracy and human rights, are needed in order to achieve a multicultural 'Rainbow' nation.

Economic redress involves financial compensation and/or the restitution of property/land to individuals, groups, or their descendants. It also involves more general redistribution of land and services for all those who suffered severe restrictions and trauma. Economic redress is one form of achieving socio-economic rights that empowers those who have been excluded. The TRC recommended a range of economic reparations, only some of which have been carried out by the state. In South Africa the origins of conflict are not only political and ethnic but also economic/resourcebased. Therefore, economic transformation is required.

Land reform policy in South Africa aims to provide economic redress and security in three ways:

1. The restitution of land and property that had been taken from people from the 1913 Land Act onwards. Almost 75,000 claims (representing almost 1.5 million people and $95 \%$ of all claims lodged) have been processed to date. The majority of these were urban claims which are now complete, with compensation primarily financial. In rural areas, the return of land is the primary form of compensation and there are over 4,000 outstanding complex claims;

2. The redistribution of $30 \%$ of agricultural land to those who would wish to farm, under a model recommended by the World Bank. Rather than expropriation (compulsory purchase), the state provides grants to enable the purchase of land. This is termed a willing-buyer, willing-seller model;

3. The securing of tenure rights for those living and working on commercial farms and those living in the former Bantustans under tribal leaders, in particular to eliminate evictions.

Current government targets are to complete restitution by 2012 and the redistribution of $30 \%$ of white-owned agricultural land by 2014 (although this may be pushed back to 2025). 


\section{A Polarised Debate: Where does the government stand?}

Land reform has been controversial from its very inception. While a majority of blacks, coloureds and Indians support the return of land, recent research highlights few whites do so. Furthermore, few whites believe that land inequality is due to historical reasons. Commercial farmers, agri-businesses and some research groups fear that land reform could damage the economy and food production, like Zimbabwe's violent land reform. The South African Centre for Development and Enterprise said in a 2008 report that land reform "could result in a dramatic decline in exports, and a withdrawal of international investment". This is echoed by a statement (February 2009) from AgriSA, the commercial farmers union, that "Excessive focus on the industry's transformation challenges and social functions, to the detriment of its core functions, namely competitive and sustainable food production, detracts from the ability of the sector to perform optimally."

On the other hand, land organisations, social movements and some academics argue that land inequality is unsustainable and land reform should help the poor secure stable livelihoods. These groups argue that the government should expropriate land and that "the right to agrarian reform by landless poor and small scale farmers is being undermined in favour of a market-based model that has led to the concentration of land" (Surplus Peoples Project 2009). They are also worried that tenure reform has been neglected and the power of dictatorial tribal leaders strengthened. What's more, over $1 \mathrm{~m}$ farm dwellers and workers have been evicted from white-owned farms since 1994. Rather than a free-market, chemical-industrial model of farming, social movements propose smaller scale ecological farming and local food sovereignty, i.e. the right of people to democratically decide their own agricultural and food policies.

While the debate converges in a criticism of the government, it is highly polarised on what kind of reform is required and the kind of economic/agricultural system that should be developed. The government has steered a course between the two sides of the debate. Influenced by internal and powerful global forces, the 1996 Growth Employment and Redistribution policy (GEAR) has embraced global capitalism, "making South African agriculture more competitive and efficient" (ministerial speech, 30 July 2008). In 2008, the Department of Rural Development and Land Reform developed the Land and Agrarian Reform Project (LARP) to concentrate on creating black commercial farming. This requires matching inputs from applicants (like money, labour, machinery) to get grants and focuses on "tradable and exportable goods" (LARP, 2008).

At the same time, the government says it is committed to redressing the imbalances caused by colonialism and apartheid. It speaks of "including the historically disadvantaged in the agricultural economy" and "promoting sustainable livelihoods" (LARP, 2008). However the government shelved the 2008 Expropriation Bill (designed to legalise compulsory purchase incorporating fair and equitable compensation) after opposition from farmers' 
groups and opposition political parties. Furthermore, according to recent government estimates, $90 \%$ of redistributed farms may have failed. Many critics attribute this to the low budgets and staffing allocated to land reform and the adoption of a free-market model that means little support (financial or otherwise) is given to new farmers who must compete on a global level.

\section{In Conclusion}

In recent years protests about the failure of the state to adequately provide services and redistribute to the poor have become increasingly frequent. Today, the majority of South Africa's population still live in poverty and a quarter of the population live on less than $\$ 1.25$ a day. As food prices rose in 2008 , life became even more difficult for many people. Since 1994, only $6.8 \%$ of land has been reallocated: $3 \mathrm{~m}$ hectares under redistribution and tenure, $2.6 \mathrm{~m}$ hectares under restitution. The 2002 Census on Commercial Agriculture counted just 45,818 farms that still possess the majority of land.

One of the main criticisms of government policy since 1994 is that political reform has been implemented, but not economic reform. It is clear that the government is rhetorically strong on reparative justice. However, the principles and implementation of its policies are not adequately pro-poor. As some commentators say, the government talks left but it walks right. Social movements feel that their voices are not heard and their influence is weak. Many businesses and whites have neglected reparative justice altogether.

The worry is that without addressing both economic and symbolic aspects of reparative justice, retribution, not reconciliation, could become a greater part of the political landscape in South Africa.

Siobhan O'Sullivan is a student in the Department of Sociology under the supervision of $\mathrm{Dr}$ Patrick O'Mahony. She would like to acknowledge funding from the Irish Research Council for the Humanities and Social Sciences and the UCC William J. Leen Fund. 